\title{
INDOMETHACIN IN THE TREATMENT OF RHEUMATIC DISEASES
}

\author{
BY
}

\author{
J. S. PERCY*, P. STEPHENSON, AND M. THOMPSON \\ From the Royal Victoria Infirmary, Newcastle-upon-Tyne
}

Indomethacin is an indole-3-acetic acid derivative (Fig. 1), which has been shown by animal experiments to possess powerful anti-inflammatory and anti-pyretic properties without evidence of toxicity other than causing diarrhoea and gastro-intestinal irritation when given in excessive dosage (Hodgkinson, 1963). Preliminary reports of its action in arthritic patients have been given at the American Rheumatism Association meeting (1963), at the European Congress of Rheumatology (1963), and by Hart and Boardman (1963). The dangers of gastro-duodenal ulceration during therapy have been stressed by Norcross (1963) and by Lövgren and Allander (1964).

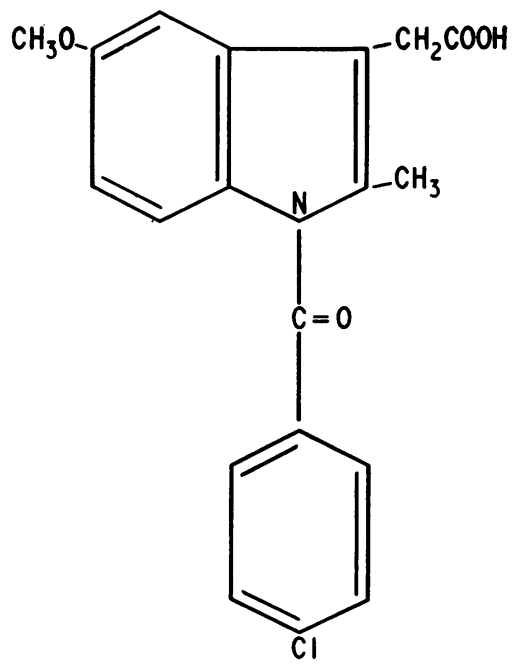

Fig. 1.-Composition of Indomethacin.

We have investigated the value of Indomethacin in the treatment of rheumatoid arthritis and various other rheumatic conditions by three methods:

* Empire Rheumatism Council Research Fellow.
(1) A pilot trial involving 23 patients given continuous treatment with initial dosage of $100 \mathrm{mg}$. twice or thrice daily;

(2) A sequential cross-over controlled trial comparing Indomethacin with phenylbutazone and using a double-blind method;

(3) A clinical study involving seventy patients employing initially low dosage of $50 \mathrm{mg}$. daily with progressively increasing dosage by $50 \mathrm{mg}$. increments at weekly intervals.

(1) Pilot Trial.-This was undertaken to assess the clinical efficacy, rapidity of action, approximate dosage requirements, and possible side-effects of Indomethacin. The group of 23 comprised eight patients with rheumatoid arthritis, seven with osteoarthritis, three with ankylosing spondylitis, three with gout, and two with acute disk lesions. The initial dosage was $100 \mathrm{mg}$. twice or thrice daily, and maintenance dosage ranged from 100 to $500 \mathrm{mg}$. daily given in 100-mg. tablets. Treatment was given for periods of 3 to 60 days. The response was considered to be excellent in six cases, good in eight, slight in eight, and nil in one. A high incidence of side-effects was noted (Table I), these being sufficient to compel withdrawal of the drug in thirteen patients. However the response of several patients in this pilot trial suggested that Indomethacin was a rapidly-acting analgesic and anti-inflammatory agent in dosages of $100 \mathrm{mg}$. twice or thrice daily, and that in those patients who could tolerate the drug the level of clinical effectiveness approached that of phenylbutazone.

TABLE I

SIDE-EFFECTS IN PILOT TRIAL

\begin{tabular}{lllll|r}
\hline Headache & $\ldots$ & $\ldots$ & $\ldots$ &.. & 16 \\
Vertigo & $\ldots$ & $\ldots$ & $\ldots$ & $\ldots$ & 12 \\
Nausea & $\ldots$ & $\ldots$ & $\ldots$ & $\ldots$ & 6 \\
Psychic & $\ldots$ & $\ldots$ & $\ldots$ & $\ldots$ & 5 \\
Diarrhoea & $\ldots$ & $\ldots$ & $\ldots$ & $\ldots$ & 2 \\
Somnolence & $\ldots$ & $\ldots$ & $\ldots$ & $\ldots$ & 1 \\
\hline
\end{tabular}

18 out of 23 patients ( 78 per cent.) had a total of 42 symptoms 
(2) Sequential Trial.-A sequential cross-over controlled trial, using a double-blind method and comparing Indomethacin with phenylbutazone, was therefore undertaken. The dosage of Indomethacin was $200 \mathrm{mg}$. daily given as four tablets of $50 \mathrm{mg}$., as our pilot trial had demonstrated that this was the maximum dosage likely to be well tolerated. One week of treatment was given with each drug to each patient, the dosage of phenylbutazone being $300 \mathrm{mg}$. daily prescribed as $100 \mathrm{mg}$. tablets three times daily.

As it was not possible to produce identical tablets of both drugs, an inert tablet corresponding to each active compound was made and the four resultant tablet types (active Indomethacin; dummy Indomethacin; active phenylbutazone; dummy phenylbutazone) were so dispensed that a week's supply of each drug was given together with dummy tablets identical with the other drug. Allocation was determined by means of a restricted series of random numbers, exactly half the patients receiving phenylbutazone during the first week.

The patients in this trial were all suffering from rheumatoid arthritis and did not receive any other treatment during the 2 weeks of assessment.
Patients with a recent or remote history of peptic ulceration were excluded from the trial, as were those known to be intolerant to phenylbutazone.

Two criteria were used for assessment:

(1) The patient's preference in terms of relief of pain and stiffness;

(2) strength of hand grip as measured by a standard method using a mercury manometer.

Side-effects were also noted and recorded, and these observations were controlled in that the clinical investigator was unaware of the treatment being given, since this was allocated and dispensed separately.

The patients' preferences were plotted sequentially (Fig. 2), using an open design graph as described by Armitage (1960), which indicated, at the conventional 5 per cent. significance level, whether or not there was a difference in the number of preferences for either drug of the order of 8 to 2 . Each preference for Indomethacin was recorded as a line through one square progressing towards the upper right-hand corner at an angle of $45^{\circ}$, and each preference for phenylbutazone as a line through one square towards

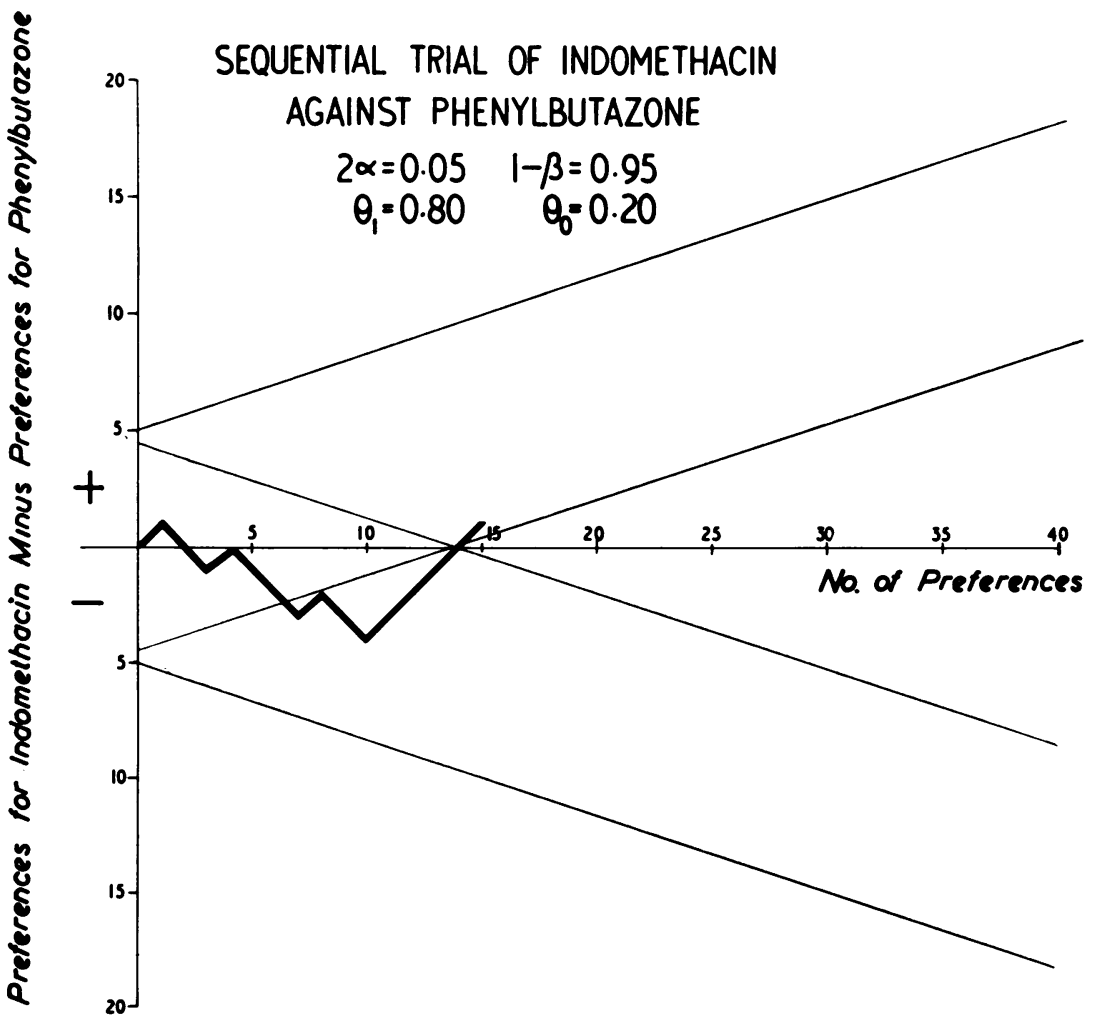

Fig. 2.-Patients' preferences. 
the lower right-hand corner, also at an angle of $45^{\circ}$. Where no preference for either drug was expressed, no record was made on the graph. If the upper boundary was crossed, then Indomethacin would have been considered as significantly better in terms of patients' preferences. If the lower boundary was crossed this would have been in favour of phenylbutazone. As, in this trial, the inner boundary was crossed there was no significant difference between the drugs in the number of preferences, at the ratio chosen and the dosage given. Of the 24 patients who completed the trial, seven expressed a preference for phenylbutazone and ten for Indomethacin, while seven had no preference.

Measurements of strength of grip were made at the beginning of the trial, and at the end of each week's therapy. The differences in grip between the two weeks of treatment were calculated and plotted in the manner described by Hajnal, Sharp, and Popert (1959). If the improvement in grip was so marked in sufficient patients as to become statistically significant, then the line would cross the upper border of the graph. If the lower border was crossed, there would be no significant difference. It was shown in this trial that there was no significant difference between Indomethacin and phenylbutazone in terms of strength of grip (Fig. 3).

Correlation between patients' preferences and improvement as measured by increased strength of grip was remarkably good.

The side-effects noted during the 2 weeks of therapy in 24 patients are listed in Table II. The increased number of side-effects attributed to Indomethacin in comparison with phenylbutazone is highly significant.

TABLE II

CONTROLLED TRIAL

Side-effects in 24 patients

\begin{tabular}{|c|c|c|c|c|}
\hline & & & Indomethacin & Butazolidin \\
\hline \multicolumn{2}{|c|}{ Headache + psychic } & \multirow{8}{*}{$\begin{array}{l}\ldots \\
\cdots \\
\cdots \\
\cdots \\
\cdots\end{array}$} & \multirow{7}{*}{$\begin{array}{l}7 \\
5 \\
2 \\
5 \\
3 \\
3 \\
2\end{array}$} & \multirow{7}{*}{$\begin{array}{l}1 \\
1 \\
0 \\
1 \\
2 \\
1 \\
0\end{array}$} \\
\hline Vertigo ... & . & & & \\
\hline Tinnitus & $\ldots$ & & & \\
\hline Epigastric pain & .. & & & \\
\hline Nausea $\quad .$. & .. & & & \\
\hline Vomiting .. & .. & & & \\
\hline \multirow[t]{2}{*}{ Diarrhoea . } & \multirow[t]{2}{*}{$\cdots$} & & & \\
\hline & & & 27 & 6 \\
\hline \multicolumn{3}{|c|}{ No. of patients } & 13 & 3 \\
\hline
\end{tabular}

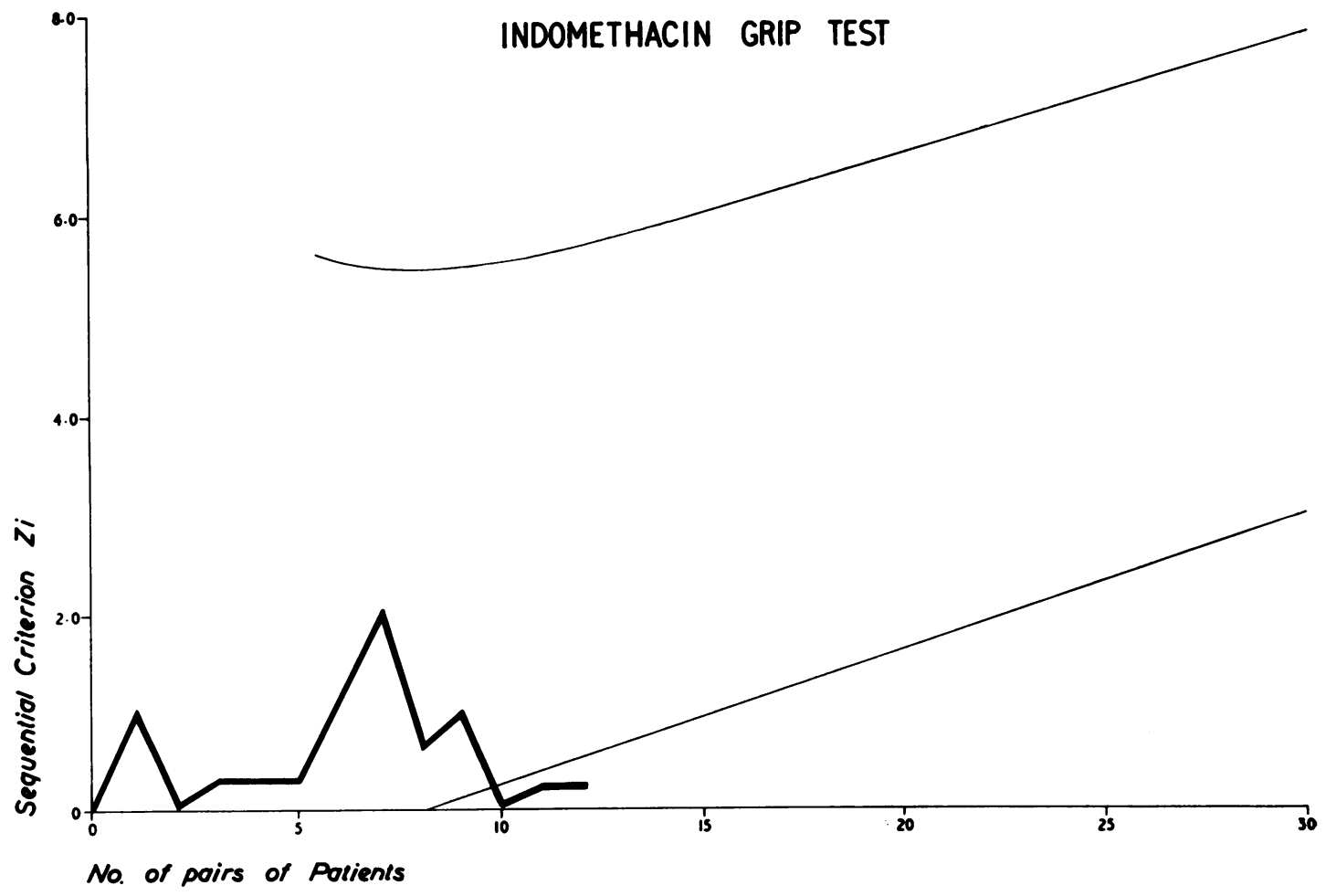

Fig. 3.-Strength of grip. 
(3) Low Dosage Regime.-A clinical study was undertaken using an initially low dosage regime of $50 \mathrm{mg}$. daily for 1 week, increasing at weekly or fortnightly intervals, by $50 \mathrm{mg}$. levels, to a limit of $200 \mathrm{mg}$. daily. Dosage was stabilized at the level at which an adequate therapeutic response was obtained. If side-effects developed and persisted in the absence of therapeutic response, then the drug was discontinued. If side-effects developed while the patient was obtaining benefit, then the daily dosage was reduced by $50 \mathrm{mg}$. and treatment was continued so long as the side-effects cleared and the patient continued to obtain a worth-while therapeutic response. If a dosage of $200 \mathrm{mg}$. was reached without side-effects or without adequate therapeutic response, the treatment was discontinued.

Seventy patients have been treated by this progressive dosage regime and the results are shown in Table III. Duration of treatment ranged from 7 to 148 days (mean 45 days). It is evident that the results from this progressive dosage regime were better than those from our two previous trials, as the failure rate has fallen from 55 to 28.6 per cent. Adequate therapeutic benefit was obtained in 61 per cent. and was considered superior to previous therapy in 34 per cent. The response of the 45 patients suffering from rheumatoid arthritis was strikingly similar to that of the 25 remaining patients in the group.

Fifteen of these patients were concurrently receiving corticosteroids, and of this group, six had to stop Indomethacin because of side-effects, two had mild side-effects, and seven had none. It seemed probable, therefore, that steroid therapy did not influence the incidence or severity of the side-effects caused by Indomethacin.

Seventeen of these patients were taking phenylbutazone, and three had been taking oxyphenbutazone immediately before the course of Indomethacin. Of these twenty patients, seven preferred Indomethacin and have continued with this drug without sideeffects, seven considered the drugs to be equally effective (but only three of them have been able to continue with Indomethacin), and six preferred phenylbutazone irrespective of the presence or absence of side-effects due to Indomethacin. These results closely resemble those obtained from the controlled trial and indicate that Indomethacin was therapeutically as effective as phenylbutazone, but that in the patients selected the advantage lay with phenylbutazone because of the higher incidence of side-effects with Indomethacin.

\section{Discussion}

It was clear from our experience in the pilot trial that Indomethacin was a potent drug capable of giving remarkable relief of symptoms and reduction of inflammatory signs in some patients. Benefit was not limited to the inflammatory arthritic disorders, as some patients suffering from apparently uncomplicated degenerative joint disease also obtained relief. Although we did not encounter any serious side-effects, the value of the drug was limited by the high incidence of unacceptable symptoms, notably headache, vertigo, light-headedness with mild confusion, and nausea. A dosage of $200 \mathrm{mg}$. daily appeared to be the maximum which could usually be tolerated, and even at this dosage over 50

TABLE III

INDOMETHACIN PROGRESSIVE DOSAGE REGIME

\begin{tabular}{|c|c|c|c|c|c|c|c|c|c|c|}
\hline \multicolumn{6}{|c|}{ Diagnosis } & \multirow{2}{*}{$\begin{array}{c}\begin{array}{c}\text { Number } \\
\text { Treated }\end{array} \\
45\end{array}$} & \multirow{2}{*}{$\begin{array}{c}\begin{array}{c}\text { Very } \\
\text { Good }\end{array} \\
16\end{array}$} & \multirow{2}{*}{$\begin{array}{c}\text { Good } \\
11\end{array}$} & \multirow{2}{*}{$\begin{array}{c}\text { Slight } \\
4\end{array}$} & \multirow{2}{*}{$\begin{array}{c}\text { Failed } \\
14\end{array}$} \\
\hline Rheumatoid art & thritis & .. & . & .. & .. & & & & & \\
\hline Osteo-arthrosis & .. & $\ldots$ & . & .. & .. & 9 & 4 & 1 & 2 & 2 \\
\hline Spondylosis & .. & .. & . & .. & .. & 5 & 2 & 2 & 0 & 1 \\
\hline Ankylosing spo & ndylitis & $\ldots$ & . & .. & . & 5 & 1 & 2 & 1 & 1 \\
\hline Gout $\quad$. & .. &.. & .. & .. & .. & 3 & & 2 & & 1 \\
\hline Shoulder-hand- & syndron & & . & .. & .. & 1 & 1 & & & \\
\hline Polymyalgia rh & eumatic & & $\ldots$ & .. & .. & 1 & & & & 1 \\
\hline Scleroderma & . & .. & . & .. & .. & 1 & & 1 & & \\
\hline \multirow{2}{*}{ Total } & \multirow{2}{*}{. } & \multirow{2}{*}{$\cdots$} & \multicolumn{3}{|c|}{ No. } & 70 & 24 & 19 & 7 & 20 \\
\hline & & & \multicolumn{3}{|c|}{ Per cent. } & 100 & $34 \cdot 3$ & $27 \cdot 1$ & $10 \cdot 0$ & $28 \cdot 6$ \\
\hline
\end{tabular}


per cent. of patients developed some side-effects. Indeed some patients reacted adversely to a dose of one $100 \mathrm{mg}$. tablet. It was also noted that some patients obtained benefit from a dosage of $100 \mathrm{mg}$. daily.

The controlled sequential trial indicated that Indomethacin $200 \mathrm{mg}$. daily was not significantly different from phenylbutazone $300 \mathrm{mg}$. daily in terms of symptomatic relief and improvement in strength of grip. The overall advantage lay with phenylbutazone in view of the significantly lower incidence of side-effects, though no patients with known intolerance to this drug were admitted to the trial. In many cases side-effects with Indomethacin developed within 2 days of starting therapy and sometimes improved as treatment continued. This suggested that the initial loading dosage of $200 \mathrm{mg}$. daily, even in divided dosage of $50 \mathrm{mg}$. 6-hourly, was excessive.

For this reason a number of patients were given continuous treatment employing an initially low dosage of Indomethacin, $50 \mathrm{mg}$. daily, with progressive increase of dosage. This regime substantially reduced the incidence and severity of sideeffects in the seventy patients treated, as the failure rate was reduced from 55 per cent. in the sequential trial to 29 per cent. The side-effects were identical with those noted in the pilot and sequential trials, with the addition of stomatitis and oedema of the ankles in one patient. No serious gastro-intestinal complications have been encountered, although faecal occult blood tests were positive in four cases out of ten tested. All patients on the pilot and progressive dosage trials have had regular haematological investigation and tests of hepatic and renal function have been undertaken in 10 patients receiving long-term dosage without any evidence of toxicity.

We compared Indomethacin with phenylbutazone since these compounds appeared to have many similarities in their clinical effect, notably the striking benefit achieved in cases of acute gout, ankylosing spondylitis, and osteo-arthritis of the hip. Although, in the controlled trial, the advantage lay with phenylbutazone, it must be remembered that 12 years of clinical experience, in addition to studies of plasma and urine concentrations, have resulted in considerable knowledge concerning the selection of patients, dosage levels, and side-effects of this drug. Furthermore, our experience with Indomethacin has hitherto been restricted to the use of tablets which were found to harden on storage and to have a variable dissolution rate. It is possible that slow dissolution may have caused gastric irritation and that variable absorption rates may have been responsible for lack of response or unduly severe side-effects in some cases. In these circumstances, we can say that Indomethacin promises to occupy a place in the management of rheumatic disorders, and it is hoped that improved preparations of the compound, with more rapid dissolution and more uniform absorption, may give improved therapeutic response with fewer side-effects.

\section{Summary}

A controlled, sequential, cross-over trial, using a double-blind method, was used to compare Indomethacin $200 \mathrm{mg}$. daily with phenylbutazone 300 mg. daily in the treatment of rheumatoid arthritis. No significant difference was found in terms of symptoms and strength of grip, but phenylbutazone was preferred in view of a lower incidence of sideeffects.

Clinical experience with Indomethacin is also reported in the treatment of various rheumatic disorders in two uncontrolled clinical trials, using a high-dosage regime (23 patients) and a low-dosage regime with progressive increase of dosage (70 patients). Side-effects were reduced by the lowdosage regime but were still frequent, compelling withdrawal of treatment in 29 per cent. of patients. No serious side-effects were encountered, although major gastro-duodenal catastrophes have been reported by others. Headache, vertigo, nausea, a feeling of drunkeness, and dyspepsia were the commonest symptoms and rapidly cleared when the drug was withdrawn.

Indomethacin was found to be particularly useful in the treatment of acute gout, ankylosing spondylitis, and osteo-arthritis, and in some cases of severe rheumatoid arthritis.

We wish to thank Drs. R. Hodgkinson and J. J. F. Merry of Merck, Sharp and Dohme for their advice and for supplies of Indomethacin. We also thank Mr. H. H. Poole, chief pharmacist at the Royal Victoria Infirmary, for his help in the organization of the controlled trial, and Nurse A. E. Kinghorn and Miss P. Port for their assistance.

\section{REFERENCES}

Armitage, P. (1960). "Sequential Medical Trials". Blackwell, Oxford.

Hajnal, J., Sharp, J., and Popert, A. J. (1959). Ann. rheum. Dis., 18, 189.

Hart, F. Dudley, and Boardman, P. L. (1963). Brit. med. J., $2,965$.

Hodgkinson, R. (1963). Personal communication.

Lövgren, O., and Allander, E. (1964). Brit. med. J., 1, 118.

Norcross, B. M. (1963). Arthr. and Rheum., 6, 290. 


\section{Indométhacine dans le traitement des maladies rhumatismales}

\section{RÉSUMÉ}

Un essai contrôlé par l'analyse séquentielle, le système de cross-over, et la méthode de double-blind fut conduit pour comparer l'Indométhacine $\mathbf{2 0 0} \mathrm{mg}$. par jour avec la phénylbutazone $300 \mathrm{mg}$. par jour dans le traitement de l'arthrite rhumatismale. On ne trouva pas de différence significative en ce qui qui concerne les symptômes et la force de l'étreinte des mains, mais la phénylbutazone fut préférée en raison de la moindre fréquence des effets secondaires.

On rapporte aussi les résultats de deux essais en clinique (sans l'emploi de témoins) de l'Indométhacine dans le traitement de divers troubles rhumatismaux par des doses fortes ( 23 malades) et par des doses faibles progressivement augmentées (70 malades). Les effets secondaires furent réduits lors de l'emploi de faibles doses, mais ils étaient encore assez fréquents pour forcer l'interruption du traitement en 29 pour cent des malades. On n'observa pas d'effets secondaires graves, bien que d'autres auteurs aient rapporté de majeures catastrophes gastro-duodénales. La céphalée, le vertige, des nausées, la sensation d'ivresse et la dyspepsie furent les symptômes le plus habituels; ils disparurent rapidement lorsqu'on suspendit le traitement.

On trouva l'Indométhacine particulièrement utile dans le traitement de la goutte aiguë, de la spondylarthrite ankylosante, de l'ostéoarthrite et de quelques cas sévères d'arthrite rhumatismale.
Indometacina en el tratamiento

de las enfermedades reumáticas

\section{SUMARIO}

Se realizó un ensayo controlado, con análisis secuencial, sistema de cross-over y método de double-blind para comparar el producto Indometacina $200 \mathrm{mg}$. al día con la fenilbutazona $300 \mathrm{mg}$. al día en el tratamiento de artritis reumatoide. No se halló diferencia significativa respecto a síntomas y a la fuerza de empuñamiento, pero la fenilbutazona fué preferida porque causaba menos efectos secundarios.

Se relatan también los resultados de dos ensayos clínicos (sin uso de testigos) de Indometacina en el tratamiento de varios disturbios reumatoides con dosis fuertes ( 23 enfermos) y con dosis pequeñas pero crecientes (70 enfermos). Con el empleo de las dosis pequeñas se logró una reducción de los efectos secundarios, pero estos fueron aun bastante frecuentes para necesitar la interrupción del tratamiento en un 20 por ciento de los enfermos. Efectos secundarios graves no se observaron, aunque otros autores hayan relatado mayores catástrofes gastro-duodenales. Dolor de cabeza, vértigo, náusea sensación de embriaguez y dispepsia ocurrían más comunamente y desaparecian rápidamente al interrumpir el tratamiento.

Indometacina reveló su utilidad particular en el tratamiento de la gota aguda, de la espondilartritis anquilosante, de la ósteoartritis y de algunos casos graves de artritis reumatoide. 